\title{
EFFICIENT DETERMINATION AND PESTICIDE CONTROL BY MEANS OF IMMOBILIZATION OF ACETYLCHOLINESTERASE
}

\author{
Elvan Hasanoğlu Özkan ${ }^{1}$, Nurdan Kurnaz Yetim ${ }^{1,2}$, Murat Gümüş ${ }^{1}$, Nurşen Sarr $^{1 *}$, Ali Dişlii ${ }^{1}$ \\ ${ }^{1}$ Department of Chemistry, Faculty of Science, Gazi University, 06500 Teknikokullar, Ankara, Turkey \\ ${ }^{2}$ Kirklareli University, Faculty of Arts and Science, Department of Chemistry, Kirklareli, Turkey \\ nursens@gazi.edu.tr
}

\begin{abstract}
Supports involving tetrazole $(o / m / p$-F-Tet- $1 H)$ were prepared to detect pesticides. This novel tetrazole including fluorine in different positions was attached to nanoparticles (2AEPS- $(o / m / p$-F-Tet- $1 H)$ ) by a condensation method. Primarily, the tetrazole derivatives were characterized by ${ }^{1} \mathrm{H}-\mathrm{NMR},{ }^{13} \mathrm{C}-\mathrm{NMR}$ and LC-MS. Then, nanoparticles were prepared by a condensation method in non-aqueous medium and characterized by Fourier transform infrared spectroscopy, scanning electron microscopy, gel permeation chromatography. The enzymatic properties of immobilized acetylcholinesterase (AChE) were investigated for the determination of phosmet. This research is the first example.
\end{abstract}

Keywords: acetylcholinesterase; nanoparticle; hazardous materials; tetrazole; immobilization

\section{ЕФИКАСНО ОПРЕДЕЛУВАЊЕ И КОНТРОЛА НА ПЕСТИЦИДИ ПО ПАТ НА ИМОБИЛИЗАЦИЈА НА АЦЕТИЛХОЛИНЕСТЕРАЗА}

Со цел да се детектираат пестициди беа подготвени подлоги во кои се наоѓа тетразолот $(o / m / p$-F-Tet-1H). Овие нови тетразоли што содржат флуор во разни положби беа прикачени на наночестички (2AEPS- $(o / m / p$-F-Tet- $1 H)$ ) со методот на кондензација. Најпрвин дериватите на тетразолот беа карактеризирани со помош на ${ }^{1} \mathrm{H}-\mathrm{NMR},{ }^{13} \mathrm{C}-\mathrm{NMR}$ и LC-MS. Потоа наночестичките беа синтетизирани со методот на кондензација во неводна средина, а карактеризирани со Фуриеова трансформна инфрацрвена спектроскопија, скенирачка електронска микроскопија и гелпродирачка хроматографија. Беа испитани ензимските својства на имобилизираната ацетилхолинестераза (AChE) за определување на фосмет.

Клучни зборови: ацетилхолинестераза; наночестички; штетни матерјали; тетразол; имобилизација

\section{INTRODUCTION}

Tetrazoles are nitrogen-rich stable heterocyclic compounds that are studied extensively due to their wide range of applications [1].They play important roles in medicinal chemistry [2, 3], and have been important in material science, including as propellants and explosives [4]. Effective methods have been reported in the literature during the past few years for the synthesis of tetrazoles [5]. The use of nanospheres in the synthesis of tetrazoles is one of these methods known to be effi- cient and economical [6, 7]. Nanospheres have advantages due to their small size and large surface area. These advantages lead to a wide variety of applications as catalyst supports. Nanosphere structures have attracted great attention in preparing advanced materials for biosensing applications [8]. In particular, polymeric nanoplatform materials have attracted significant interest for their potential application in enzyme immobilization [9].

It is known, that enzymes are immobilized by interactions between the support and the enzyme by covalent bonding, hydrogen bonding and 
Van der Waals forces [10]. If a polymer-based nanosphere support contains electronegative groups such as oxygen, nitrogen and fluorine this may be useful for increasing the enzyme stability via hydrogen bonding attachment [11]. So, the surface on which the enzyme is immobilized has several vital roles to play, such as retaining the tertiary structure of the enzyme through hydrogen bonding.

Acetylcholinesterase (AChE) is crucial enzyme in the central nervous system of living organisms [12]. The inhibition of AChE activity by organophosphorus (OP) compounds is an irreversible process. In this process, $\mathrm{AChE}$ is deactivated. OP compounds, are commonly used as insecticides [13]. Acetylcholinesterase (AChE) is a serine protease enzyme. The inhibition of AChE catalytic activity by OP compounds is caused by the phosphorylation of the serine residue [14].
In this work, new tetrazole derivatives have been prepared as novel supports (Figure 1), designed to take advantage of hydrogen bonding between the enzyme and fluorine, and to improve the recycling stability performance for the determination of hazardous materials. Nanospheres were attached to these derivatives (Figure 2), and acetylcholinesterase then immobilized on the nanoparticles (Figure 3) for practical determination of Phosmet [ $N$-(mercaptomethyl) phthalimide $S$ $(O, O$-dimethyl phosphorodithioate)]. Phosmet is a phthalimide-derived organophosphate insecticide used on plants and animals, mainly used on apple trees for the control of codling moth. The experimental results showed that immobilized nanoparticles supports showed excellent results for the determination of pesticides.

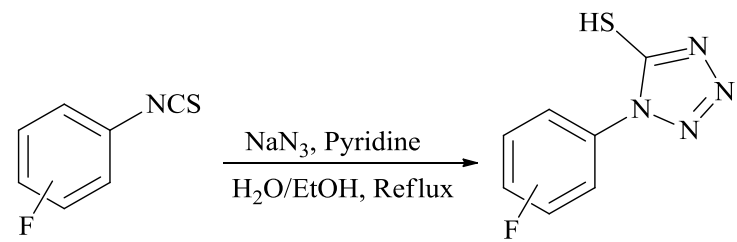

(A); yield 54\%

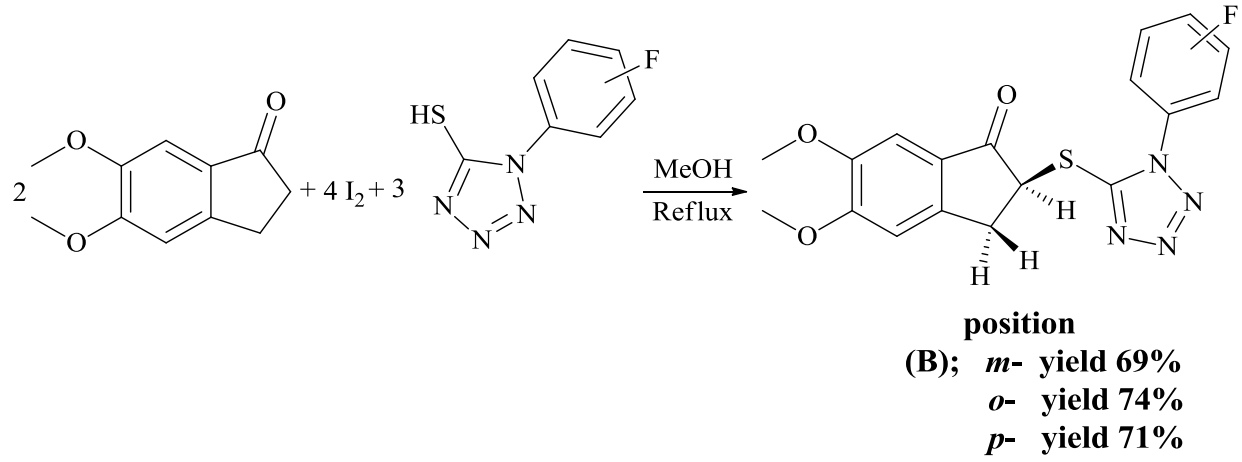

Fig. 1. Synthesis rotation of 1-([o-, $m-, p$-]fluorophenyl)-1 $H$-tetrazole-5-thiol (A) and 2-(([o-, $m-, p$-]fluorophenyl)-1 $H$-tetrazol-5-yl)thio)-5,6-dimethoxy-2,3-dihydro-1 $H$-inden-1-one (B)
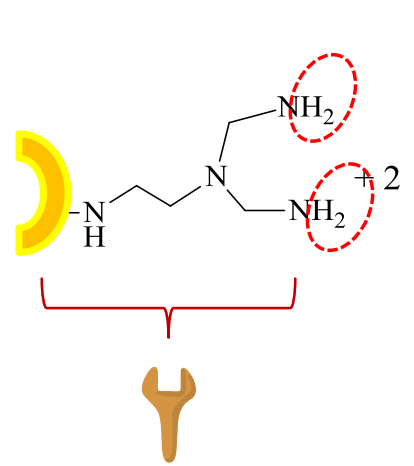
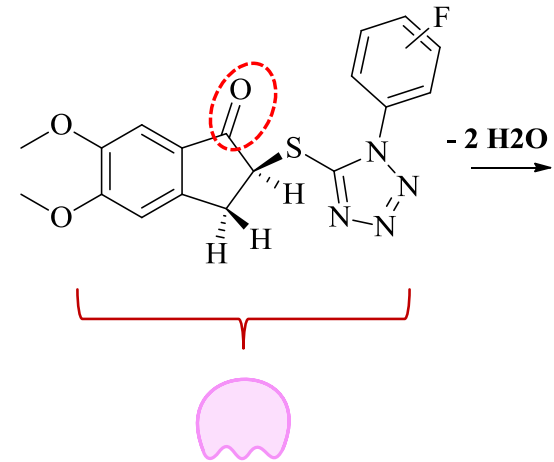

Fig. 2. Formation of Schiff bases including tetrazole on nanosphere<smiles>[H][Z11]1c2cc(OC)c(OC)cc2[C@H](Sc2nnnn2-c2ccccc2)[C@H]1Sc1nnnn1-c1ccc(F)cc1</smiles> 


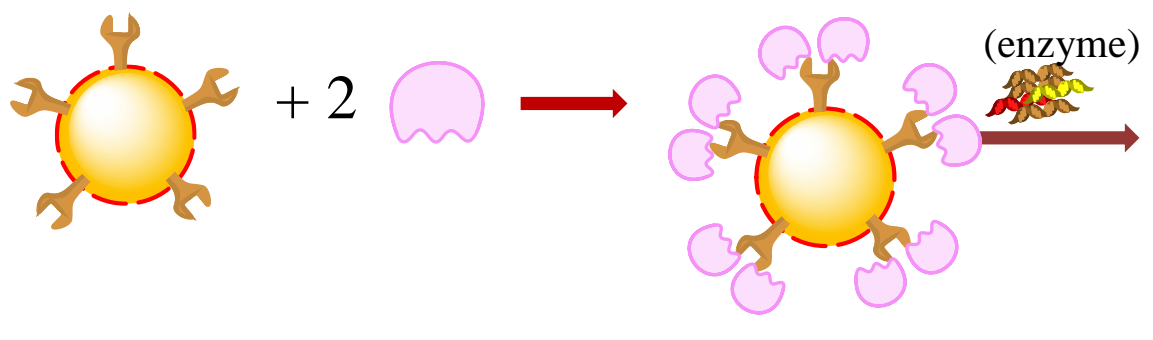

Fig. 3. AChE immobilization on studied nano-support

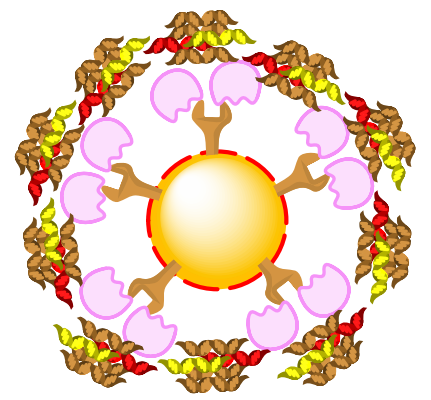

\section{EXPERIMENTAL}

\subsection{Materials and methods}

The $o-, m-$, and $p$-fluorophenyl isothiocyanates, $N$-\{2-[bis(2-aminoethyl)amino] ethyl $\}$ aminomethyl-polystyrene, acetylcholinesterase (Type C3389, from electric eel, 518 units/mg, 10KU), 5,5'dithiobis(2-nitrobenzoic acid), acetylthiocholine iodide, and $\mathrm{N}$-(mercaptomethyl) phthalimide $S$ - $(O, O$ dimethyl phosphorodithioate) were purchased from Sigma (St. Louis, MO) and other chemicals were obtained from Sigma-Aldrich. All melting points were determined in sealed capillaries and are reported without correction for tetrazole derivatives. FT-IR/ATR spectra were recorded on a Mattson 1000 spectrometer or a Thermo Nicolet 6700 spectrometer as $\mathrm{KBr}$ pellets. ${ }^{1} \mathrm{H}-\mathrm{NMR}$ spectra were recorded on a Varian Gemini 300 (300 MHz) NMR spectrometer in dimethyl sulfoxide (DMSO) $-\mathrm{d}^{6}$ and $\left(\mathrm{CHCl}_{3}\right)-\mathrm{d}^{1} .{ }^{13} \mathrm{C}-\mathrm{NMR}$ spectra were recorded on a Varian Gemini $300(75 \mathrm{MHz})$ NMR spectrometer in dimethyl sulfoxide (DMSO)- $\mathrm{d}^{6}$ and $\left(\mathrm{CHCl}_{3}\right)-\mathrm{d}^{6}$. Mass spectra measurements were recorded on a Thermo Finnigan Trace DSQ. The GPC measurements were recorded on a Waters 1500 Series Gel permeation chromatography (GPC). Scanning electron microscopy of the Au-Pd-coated compounds was performed by a JEOL JEM 100 CX II scanning electron microscope (JEOL, Peabody, MA) equipped with a Link analytical system. The electron energy used was $20 \mathrm{keV}$.

\subsection{Preparation of 1-substituted phenyl-1H-} tetrazol-5-thiol from organic phenylisothiocyanates

$2.5 \mathrm{mmol}$ of sodium azide $\left(\mathrm{NaN}_{3}\right)$ was dissolved in $10.0 \mathrm{ml} \mathrm{H}_{2} \mathrm{O} / \mathrm{EtOH}$ (3/1). Then, 3.0 mmol of pyridine and $1.0 \mathrm{mmol}$ of $[o-, m-, p-$ ]fluorophenyl isothiocyanate derivatives were added to the solution, respectively. The mixture was refluxed for about $16 \mathrm{~h}$ and the reaction was monitored by TLC. EtOH from the crude reaction mix- ture was removed under vacuum. The ethyl acetate $(10 \mathrm{ml})$ was added to the mixture and organic layer was extracted three times with water. The aqueous layer was collected and acidified with $3 \mathrm{M} \mathrm{HCl}$ to pH 1-2. 1-([o-, $m$-, $p$-]fluorophenyl)-1H-tetrazole5 -thiol was precipitated as white solid. This solid was filtered, washed with $\mathrm{H}_{2} \mathrm{O}$ and dried [15-18].

\subsection{Preparation of 2-fluorophenyl-1H-tetrazol-5- yl)thio)-5,6-dimethoxy-2,3-dihydro-1H-inden-1- one}

$3.0 \mathrm{mmol}$ of 1-([o-, $m$-, $p$-]fluorophenyl)$1 \mathrm{H}$-tetrazole-5-thiol was dissolved in $10.0 \mathrm{ml}$ of $\mathrm{MeOH}$. $4.0 \mathrm{mmol}$ of $\mathrm{I}_{2}$ and $2.0 \mathrm{mmol}$ of 5,6dimethoxy-2,3-dihydro- $1 H$-inden-1-one was added over the solution, respectively, and the mixture was refluxed for about $18 \mathrm{~h}$. Then, $4.5 \mathrm{ml} \mathrm{H}_{2} \mathrm{O}$ was added to the mixture and extracted with ethyl acetate $(3 \times 10 \mathrm{ml})$. The collected organic layer was extracted with $10 \%$ anhydrous sodium thiosulfate solution $(2 \times 10 \mathrm{ml})$ to remove excess $\mathrm{I}_{2}$. Then, the organic layer was dried over anhydrous sodium sulfate, filtered and the solvent removed under vacuum. The obtained solid was recrystallized with ethyl acetate/acetone.

\subsection{Synthesis of nanomaterial (2AEPS- $(\mathrm{o} / \mathrm{m} / \mathrm{p}-\mathrm{F}-\mathrm{Tet}-1 \mathrm{H}))$}

The nanomaterial containing tetrazole derivatives were prepared by dropwise addition of $N-\{2-$ [bis(2-aminoethyl)amino] ethyl \}aminomethyl-polystyrene [(2AEPS), 1 g, 200-400 mesh, 3.5-5.0 $\mathrm{mmol} / \mathrm{g} \mathrm{N}$ loading, $1 \%$ cross-linked with divinylbenzene (Aldrich)] in hot DMF $(10 \mathrm{ml})$ to a solution of tetrazole derivatives $(7 \mathrm{mmol})$ in DMF $(10 \mathrm{ml})$ with stirring. The stirring was continued at room temperature and under $\mathrm{N}_{2}(\mathrm{~g})$. Then mixture was poured into acetone $(30 \mathrm{ml})$. The resulting solid 2AEPS- $(o / m / p$-F-Tet- $1 H)$ was collected from the acetone. The solid was filtered and dried and kept in a desiccator over anhydrous $\mathrm{CaCl}_{2}$. 


\subsection{Immobilization of AChE on nanomaterial 2AEPS- $(\mathrm{o} / \mathrm{m} / \mathrm{p}-\mathrm{F}-\mathrm{Tet}-\mathrm{HH})$}

After dissolving the enzyme in pure water $\left(50 \mathrm{ml}, 3.6 \times 10^{-4} \mathrm{~g} \mathrm{l}^{-1}\right)$, 2AEPS- $(o$-F-Tet- $1 H)$, 2AEPS- $(m$-F-Tet- $1 H)$ and 2AEPS- $(p$-F-Tet- $1 H)$ polymers $(0.5 \mathrm{~g})$ were added to $2 \mathrm{ml}$ of $3.6 \times 10^{-4} \mathrm{~g}$ $\mathrm{l}^{-1}$ AChE. This solution was diluted to $10 \mathrm{ml}$ and shaken in a water bath at room temperature for $8 \mathrm{~h}$. The immobilized polymers were separated and the free enzyme was removed by washing with phosphate buffer and then stored at $+4{ }^{\circ} \mathrm{C}$. The saturation ratio was determined as $94.20,97.60$ and $93.70 \%$ for 2AEPS- $(o$-F-Tet- $1 H)$, 2AEPS- $(m$-FTet- $1 H)$ and 2AEPS- $(p$-F-Tet- $1 H)$, respectively, from the absorbance value at $412 \mathrm{~nm}$.

\subsection{Assay for enzyme activity measurement}

The catalytic activity of acetylcholinesterase (AChE) was determined by the Ellman method. In this method, acetate and thiocholine forms by hydrolysis of acetylthiocholine (ACh) by AChE. Acetylthiocholine iodide and 5,5'-dithiobis(2nitrobenzoic acid) (DTNB) are used as substrate and Ellman's reagent. 2-Nitro-5-thiobenzoate (TNB) forms as a yellow solution in water at neutral and alkaline $\mathrm{pH}$ by the reaction of DTNB with acetylthiocholine.

\subsection{Study of phosmet insecticide ( $N$-(mercaptomethyl) phthalimide $S$-(O,O-dimethyl phosphorodithioate))}

Phosmat insecticide, $N$-(mercaptomethyl) phthalimide $S$-( $O, O$-dimethyl phosphorodithioate) was dissolved in acetonitrile/ $/ \mathrm{H}_{2} \mathrm{O}\left(1.37 \times 10^{-7}\right.$ $\mathrm{mol} / \mathrm{l} ; 1 / 4, \mathrm{v} / \mathrm{v})$ in volumes of $10 \mu \mathrm{l}-50 \mu \mathrm{l}$. The absorbance changes at $412 \mathrm{~nm}$ were taken into account for studied phosmate solutions.

\subsection{Effect of $\mathrm{pH}$ and temperature on activity of free and immobilized AChE}

The optimum $\mathrm{pHs}$ for immobilized and free acetylcholinesterase were determined by measuring the activity of free and immobilized enzymes in buffers of different $\mathrm{pH}$ values ranging from 3.0 to 9.5 . For this purpose, buffers were prepared: $\mathrm{pH} 3.0-4.0\left(\mathrm{CH}_{3} \mathrm{COONa} / \mathrm{CH}_{3} \mathrm{COOH}\right) ; \mathrm{pH}$ $5.0 \quad\left(\mathrm{NaH}_{2} \mathrm{PO}_{4} / \mathrm{H}_{3} \mathrm{PO}_{4}\right) ; \mathrm{pH} \quad 6 \quad\left(\mathrm{Na}_{2} \mathrm{HPO}_{4} /\right.$ $\left.\mathrm{NaH}_{2} \mathrm{PO}_{4}\right)$; and $\mathrm{pH}$ 7.0-9.0 $\left(\mathrm{NaH}_{2} \mathrm{PO}_{4} / \mathrm{Na}_{2} \mathrm{HPO}_{4}\right)$.

For the temperature studies, immobilized and free enzymes were incubated in the reaction mixtures at different temperatures ranging from 20 to $90{ }^{\circ} \mathrm{C}$. The activities of free and immobilized enzyme were plotted against temperature.

Optimum $\mathrm{pH}$ and temperature for immobilized acetylcholinesterase the following recipe was used: $4 \mathrm{ml}$ studied buffer $(\mathrm{pH} \mathrm{3-9)}+20 \mu \mathrm{l} 0.075$ $\mathrm{M}$ acetylthiocholine $+50 \mu \mathrm{l} 0.01 \mathrm{M}$ DTNB +20 $\mathrm{mg}$ immobilized- acetylcholinesterase. The maximum activity was obtained at $\mathrm{pH} 8.0$ and temperature $40{ }^{\circ} \mathrm{C}$ for the free enzyme.

\subsection{Effect of substrate}

To determine the extent to which immobilization affected the enzyme activity, $K_{\mathrm{M}}$ and $V_{\max }$ were determined at optimum $\mathrm{pH}$ and $60{ }^{\circ} \mathrm{C}$. Free and immobilized enzyme were incubated with different substrate concentrations $(10 \mu \mathrm{l}-60 \mu \mathrm{l}$ $0.075 \mathrm{M})$ in phosphate buffer of $\mathrm{pH} 8(4010-3960$ $\mu \mathrm{l}$ ), and assayed for enzyme activity at $50-70{ }^{\circ} \mathrm{C}$, the recommended temperature for enzyme assays.

\subsection{Storage stability and reusability of immobilized enzyme}

Storage stability experiments were carried out to determine the stabilities of immobilized enzymes after storage in dry conditions at $+4{ }^{\circ} \mathrm{C}$ for 5 months. The enzyme activity was measured every 30 days and the observed results compared to the initial activities. To evaluate the reusability, the acetylcholinesterase immobilized polymeric supports were also washed with buffer solution after each run and reintroduced into fresh solution. Reaction cycles under the conditions $(\mathrm{pH}=8.0$, at room temperature) described above were performed and the enzyme activity measured.

\section{RESULTS AND DISCUSSION}

\subsection{Characterization of 2-fluorophenyl-1H- tetrazol-5-yl)thio)-5,6-dimethoxy-2,3-dihydro- $1 \mathrm{H}$ - inden-1-one}

2-((1-(o-fluorophenyl)-1 $H$-tetrazol-5-yl)thio)5,6-dimethoxy-2,3-dihydro- $1 H$-inden-1-one; m.p. 178.3-178.6 ${ }^{\circ} \mathrm{C}$; yield 74\%; IR (KBr): $\mathrm{cm}^{-1}=3075$ $(=\mathrm{C}-\mathrm{H}), 2883(-\mathrm{C}-\mathrm{H}), 1692(\mathrm{C}=\mathrm{O}), 1604(\mathrm{C}=\mathrm{C})$, $1505(\mathrm{~N}=\mathrm{N}), 1460(\mathrm{C}=\mathrm{N}), 1016(\mathrm{C}-\mathrm{O}-\mathrm{C}) ;{ }^{1} \mathrm{H}$ NMR $\left(300 \mathrm{MHz}, \mathrm{CDCl}_{3}\right): \delta=7.60-7.50(\mathrm{~m}, 2 \mathrm{H}), 7.39$ $7.31(\mathrm{~m}, 2 \mathrm{H}), 7.20(\mathrm{~s}, 1 \mathrm{H}), 6.89(\mathrm{~s}, 1 \mathrm{H}), 4.71(\mathrm{dd}$, $\left.1 \mathrm{H}, \mathrm{H}_{1} \mathrm{~J}_{\mathrm{H} 2, \mathrm{H} 1}=7,6 \mathrm{~Hz} ; \mathrm{J}_{\mathrm{H} 3, \mathrm{H} 1}=4.2 \mathrm{~Hz}\right), 4.00-3.88$ $(\mathrm{m}, 7 \mathrm{H}), 3.34\left(\mathrm{dd}, 1 \mathrm{H}, \mathrm{H}_{3}, \mathrm{~J}_{\mathrm{H} 1, \mathrm{H} 3}=3.7 \mathrm{~Hz} ; \mathrm{J}_{\mathrm{H} 2, \mathrm{H} 3}=\right.$ $17.4 \mathrm{~Hz}) \mathrm{ppm} ;{ }^{13} \mathrm{C}_{\text {NMR }}\left(75 \mathrm{MHz}, \mathrm{CDCl}_{3}\right): \delta=$ $197.7(\mathrm{C}=\mathrm{O}), 157.9,156.7,154.9,154.5,147.7$, $133.1,133.0,128.1,127.7,125.2,117.5,107.2$ 
(Ar-C), $150.0(\mathrm{C}=\mathrm{N}), 56.4,56.2\left(\mathrm{CH}_{3}\right), 50.4(\mathrm{CH})$, $35.8\left(\mathrm{CH}_{2}\right) \mathrm{ppm}$; MS: $\mathrm{m} / \mathrm{z}=387.0927[\mathrm{M}+1]^{+}$.

2-((1-( $m$-fluorophenyl)-1 $H$-tetrazol-5-yl)thio)5,6-dimethoxy-2,3-dihydro-1H-inden-1-one; m.p. $159.7-160.3^{\circ} \mathrm{C}$; yield $69 \%$; IR $(\mathrm{KBr}): \mathrm{cm}^{-1}=3067$ $(=\mathrm{C}-\mathrm{H}), 2955(-\mathrm{C}-\mathrm{H}), 1708(\mathrm{C}=\mathrm{O}), 1598(\mathrm{C}=\mathrm{C})$, $1495(\mathrm{~N}=\mathrm{N}), 1460(\mathrm{C}=\mathrm{N}) ;{ }^{1} \mathrm{H}$ NMR $(300 \mathrm{MHz}$, $\left.\mathrm{CDCl}_{3}\right): \delta=7.57-7.53(\mathrm{~m}, 2 \mathrm{H}), 7.44-7.41(\mathrm{~m}$, $2 \mathrm{H}), 7.23(\mathrm{~s}, 1 \mathrm{H}), 6.90(\mathrm{~s}, 1 \mathrm{H}), 4.76\left(\mathrm{dd}, 1 \mathrm{H}, \mathrm{H}_{1}\right.$ $\left.\mathrm{J}_{\mathrm{H} 2, \mathrm{H} 1}=7,6 \mathrm{~Hz} ; \mathrm{J}_{\mathrm{H} 3, \mathrm{H} 1}=4.2 \mathrm{~Hz}\right), 4.00-3.91(\mathrm{~m}, 7 \mathrm{H})$, $3.34\left(\mathrm{dd}, 1 \mathrm{H}, \mathrm{H}_{3}, \mathrm{~J}_{\mathrm{H} 1, \mathrm{H} 3}=4.1 \mathrm{~Hz} ; \mathrm{J}_{\mathrm{H} 2, \mathrm{H} 3}=17.4 \mathrm{~Hz}\right)$ ppm; ${ }^{13} \mathrm{C}$ NMR $\left(75 \mathrm{MHz}, \mathrm{CDCl}_{3}\right): \delta=197.6$ $(\mathrm{C}=\mathrm{O}), 164.5,161.1,156.7,153.1,147.8,131.4$, 127.7, 119.4, 117.5, 111.8, 107.2, 104.8 (Ar-C), $150.1(\mathrm{C}=\mathrm{N}), 56.4,56.2\left(\mathrm{CH}_{3}\right) 50.6(\mathrm{CH}), 35.7$ $\left(\mathrm{CH}_{2}\right)$ ppm; MS: $m / z=387.0932[\mathrm{M}+1]^{+}$.

2-((1-(p-fluorophenyl)-1 $H$-tetrazol-5-yl)thio)5,6-dimethoxy-2,3-dihydro-1 $H$-inden-1-one; m.p. 204.5-206 ${ }^{\circ} \mathrm{C}$; yield 71\%; IR (KBr): $\mathrm{cm}^{-1}=3069$ (=C-H), 2940 (-C-H), $1696(\mathrm{C}=\mathrm{O}), 1588(\mathrm{C}=\mathrm{C})$, $1504(\mathrm{~N}=\mathrm{N}), 1470(\mathrm{C}=\mathrm{N}) ;{ }^{1} \mathrm{H}$ NMR $(300 \mathrm{MHz}$, $\left.\mathrm{CDCl}_{3}\right): \delta=7.65-7.59(\mathrm{~m}, 2 \mathrm{H}), 7.31-7.23(\mathrm{~m}$, $2 \mathrm{H}), 7.22(\mathrm{~s}, 1 \mathrm{H}), 6.90(\mathrm{~s}, 1 \mathrm{H}), 4.74\left(\mathrm{dd}, 1 \mathrm{H}, \mathrm{H}_{1}\right.$ $\left.\mathrm{J}_{\mathrm{H} 2, \mathrm{H} 1}=7,6 \mathrm{~Hz} ; \mathrm{J}_{\mathrm{H} 3, \mathrm{H} 1}=4.2 \mathrm{~Hz}\right), 4,00-3,90(\mathrm{~m}$, $7 \mathrm{H}), 3.35\left(\mathrm{dd}, 1 \mathrm{H}, \mathrm{H}_{3}, \mathrm{~J}_{\mathrm{H} 1, \mathrm{H} 3}=4.1 \mathrm{~Hz} ; \mathrm{J}_{\mathrm{H} 2, \mathrm{H} 3}=17.4\right.$
$\mathrm{Hz}) \mathrm{ppm} ;{ }^{13} \mathrm{C}$ NMR $\left(75 \mathrm{MHz}, \mathrm{CDCl}_{3}\right): \delta=197.7$ $(\mathrm{C}=\mathrm{O}), 164.9,161.6,156.7,147.8,129.6,126.2$, 117.2, 107.2, 104.8 (Ar-C), $150.1(\mathrm{C}=\mathrm{N}), 56.4$, $56.2\left(\mathrm{CH}_{3}\right), 50.6(\mathrm{CH}), 35.7\left(\mathrm{CH}_{2}\right) \mathrm{ppm} ; \mathrm{MS}: \mathrm{m} / \mathrm{z}=$ $387.0926[\mathrm{M}+1]^{+}$.

\subsection{Characterization of 2AEPS-(o-F-Tet-1H), 2AEPS-(m-F-Tet-1H) and 2AEPS-(p-F-Tet-1H)}

The weight average molecular weight $(\mathrm{Mw})$ was suggested from elemental analyses. The elemental analyses can be considered compatible with the chemical formulas of the compounds. Polydispersity indexes and some of the physical properties, including tetrazole polymeric spheres, are given in Table 1 . The polydispersity index as a measure of the width of molecular weight distributions is theoretically very important. Molecular weight and molecular weight distribution (Mw/Mn) were determined by gel permeation chromatography (GPC). According to GPC, the modified polymers had a narrow molecular weight distribution (PDI: 1.30, 1.42 and 1.38 for 2AEPS$(o$-F-Tet- $1 H)$, 2AEPS- $(m$-F-Tet- $1 H)$ and 2AEPS( $p$-F-Tet-1H), respectively).

Table 1

FT-IR, GPS, elemental analysis and important physical properties of nanosphere attached tetrazole derivatives

\begin{tabular}{|c|c|c|c|}
\hline \multirow{2}{*}{$\begin{array}{l}\text { Compound } \\
\text { Color, }{ }^{*} \mathrm{M}_{\mathrm{w}}\end{array}$} & \multirow{2}{*}{$\begin{array}{l}\text { Chemical formula } \\
\left(M_{w}, M_{n}\right), \text { PDI }\end{array}$} & \multicolumn{2}{|c|}{ IR spectra } \\
\hline & & $\begin{array}{l}v_{\text {overton }} \\
\mathrm{vC}=\mathrm{C}_{(\mathrm{ar})} / \mathrm{vCH}_{(\mathrm{ar})}\end{array}$ & $\begin{array}{l}v(\mathrm{~N}=\mathrm{N}), v(\mathrm{C}=\mathrm{N}) \\
v \mathrm{CH}=\mathrm{N}\end{array}$ \\
\hline 2AEPS- $(o$-F-Tet- $1 H)$ & {$\left[\left(\mathrm{C}_{8} \mathrm{H}_{8}\right)_{6}\left(\mathrm{C}_{12} \mathrm{H}_{18} \mathrm{~N}_{4}-\left(\mathrm{C}_{18} \mathrm{H}_{15} \mathrm{O}_{2} \mathrm{SN}_{4} \mathrm{~F}\right)_{2}\right)\right]$} & $1937,1869,1801$ & 1506,1462 \\
\hline Yellow, 1582 & $(845,650), 1.30$ & $1596 / 2921$ & 1618 \\
\hline 2AEPS- $(m$-F-Tet- $1 H)$ & {$\left[\left(\mathrm{C}_{8} \mathrm{H}_{8}\right)_{6}\left(\mathrm{C}_{12} \mathrm{H}_{18} \mathrm{~N}_{4}-\left(\mathrm{C}_{18} \mathrm{H}_{15} \mathrm{O}_{2} \mathrm{SN}_{4} \mathrm{~F}\right)_{2}\right)\right]$} & 1870,1801 & 1508,1465 \\
\hline Orange, 1582 & $(923,650), 1.42$ & 1594 / 2920 & 1621 \\
\hline 2AEPS-(p-F-Tet-1H) & {$\left[\left(\mathrm{C}_{8} \mathrm{H}_{8}\right)_{6}\left(\mathrm{C}_{12} \mathrm{H}_{18} \mathrm{~N}_{4}-\left(\mathrm{C}_{18} \mathrm{H}_{15} \mathrm{O}_{2} \mathrm{SN}_{4} \mathrm{~F}\right)_{2}\right)\right]$} & 1870,1801 & \\
\hline Brown, 1582 & $(911,660), 1.38$ & 1594 / 2921 & $\begin{array}{l}150 /, 1465 \\
1618\end{array}$ \\
\hline
\end{tabular}

$\mathrm{M}_{\mathrm{w}}$ : average molecular weight; $\mathrm{M}_{\mathrm{n}}$ : molecular weight distribution;

$* \mathrm{M}_{\mathrm{w}}$ : was suggested from element analyses

\subsection{IR spectra and SEM-EDX of 2AEPS-(o-F-Tet-1H), 2AEPS-(m-F-Tet-1H) and $2 A E P S-(p-F-T e t-1 H)$}

The characteristic IR spectra peaks of 2AEPS- $(o$-F-Tet- $1 H)$-sphere, 2AEPS- $(m$-F-Tet$1 H)$-sphere and 2AEPS-( $p$-F-Tet-1H)-sphere polymers are given in Table 1 . As in our previous study, three overtone peaks showed at ca. 19378, 18710 and $1801 \mathrm{~cm}^{-1}$ in the IR spectra of support nanoplatforms attached tetrazole. IR bands $c a$
$2920,1598,1508,1465 \mathrm{~cm}^{-1}$ regions are characteristic of $v(\mathrm{CH})$ aliphatic, $v(\mathrm{C}=\mathrm{C})$ aromatic ring, $v(\mathrm{~N}=\mathrm{N})$ tetrazole ring and $v(\mathrm{C}=\mathrm{N})$ tetrazole ring, respectively $[19,20]$. The observation of band at ca $1618 \mathrm{~cm}^{-1}$ may be attributed to the $v(-\mathrm{CH}=\mathrm{N})$ stretching vibration for 2AEPS- $(o$-F-Tet- $1 H)$, 2AEPS- $(m$-F-Tet- $1 H)$ and 2AEPS- $(p$-F-Tet- $1 H)$. Furthermore, the carbonyl peak $(\mathrm{C}=\mathrm{O})$ in tetrazol derivatives disappeared due to formation of the Schiff base. These indicate that the tetrazole derivatives are attached to 2AEPS. 
As is known, EDX spectra can provide excellent elemental analysis for all elements in the Periodic Table above beryllium in a modified polymer [21]. Table 2 presents the elemental compositions of synthesized 2AEPS- $(o$-F-Tet- $1 H)$, 2AEPS- $(m$-F-Tet- $1 H)$ and 2AEPS- $(p$-F-Tet- $1 H)$ obtained from EDX analysis. As seen from the SEM image, the spherical structure is unaffected.

T a b l e 2

SEM image and elemental analysis from EDX for nanosphere-attached tetrazole derivatives

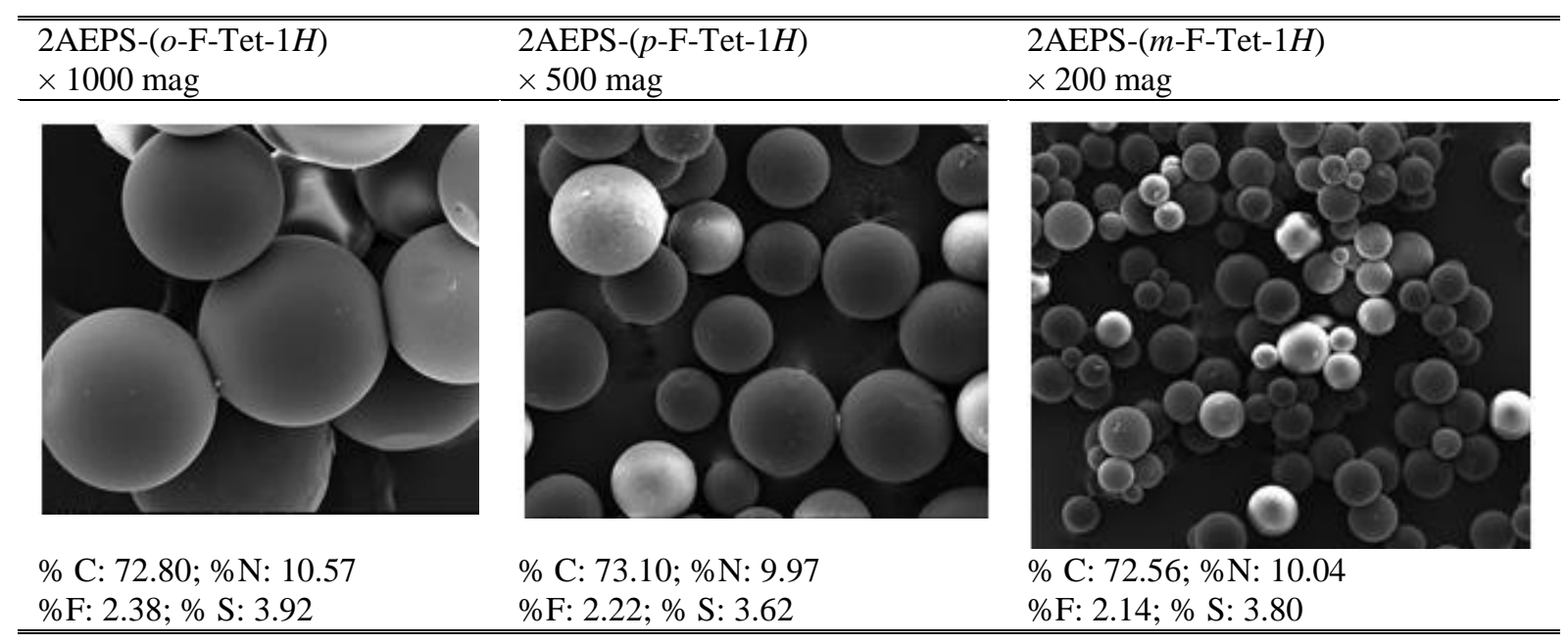

\subsection{Studies of biocatalysis}

Firstly, the amount of loaded enzyme per gram of polymer was found according to saturation ratio (s.r.) calculated according to the following formula for all three enzymes:

$$
\begin{gathered}
\mathrm{A}_{412}=\varepsilon \times \mathrm{b} \times \mathrm{C}_{20 \mu \mathrm{l}, 0.075 \mathrm{M}} \\
\mathrm{A}_{\text {s.r. }(412)}=\varepsilon \times \mathrm{b} \times \mathrm{C}_{(20 \mu \mathrm{l}, 0.075 \mathrm{M}-\text { immobilized AChE })}
\end{gathered}
$$

\subsection{Influence of $\mathrm{pH}$ and temperature on the enzyme activity}

$\mathrm{pH}$ is one of the important parameters for enzymatic activities in aqueous solution [22]. Free and immobilized supports 2AEPS- $(o$-F-Tet- $1 H)$, 2AEPS- $(m$-F-Tet- $1 H)$ and 2AEPS- $(p$-F-Tet- $1 H)$ showed the same observed maximum activities and are illustrated in Figure 4.

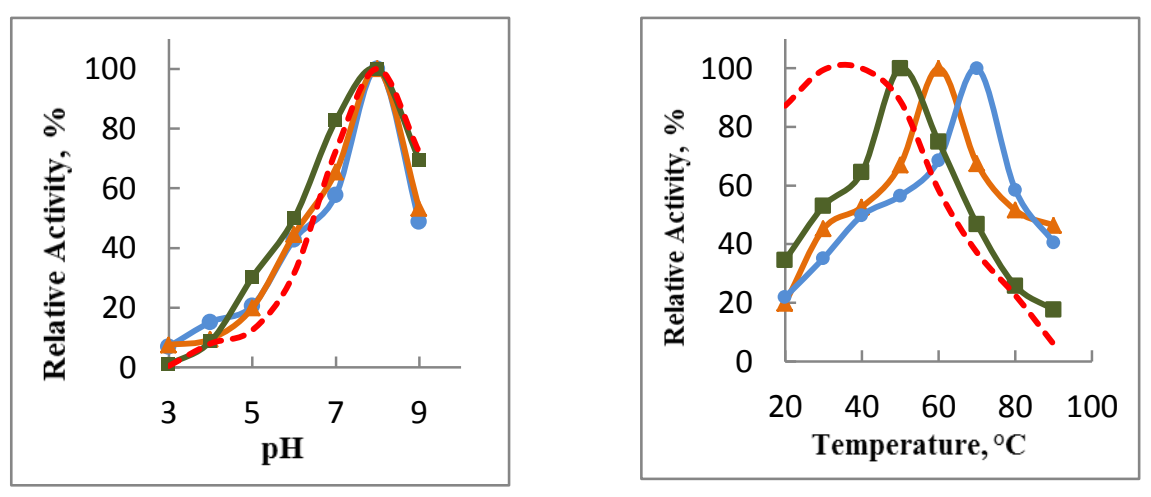

- 2AEPS- $(o$-F-Tet- $1 H)$-AChE, $\boldsymbol{\Delta}$ 2AEPS- $(m$-F-Tet- $1 H)$-AChE

- 2AEPS- $(p$-F-Tet- $1 H)$-AChE, --- free-Enzyme

Fig. 4. Effect of $\mathrm{pH}$ and temperature on the enzyme activity

Free and immobilized enzyme were incubated $(30 \mathrm{~min})$ in the reaction mixtures at different temperatures ranging from 20 to $90{ }^{\circ} \mathrm{C}$. The activities of immobilized enzyme were plotted at opti- mum temperature. The optimum temperatures for immobilized AChE on 2AEPS- $(o-$ F-Tet- $1 H)$, 2AEPS- $(m$-F-Tet- $1 H)$ and 2AEPS- $(p$-F-Tet- $1 H)$ were 50,60 and $70{ }^{\circ} \mathrm{C}$, respectively (Fig. 4). Free 
enzyme had an optimum temperature $40{ }^{\circ} \mathrm{C}$. As shown in Figure 5, the thermal stability of the enzyme increased after immobilization, indicating that the structure of the enzyme is protected at high temperature. The optimum temperature of [2AEPS- $(p$-F-Tet- $1 H)]$-AChE was higher than that of [2AEPS- $(o$-F-Tet- $1 H)]$-AChE, [2AEPS- $(m-\mathrm{F}-$ Tet-1H)]-AChE. The cause of this may be the impact of hydrogen bonding between the enzyme and fluorine. In [2AEPS- $(p$-F-Tet-1H)], the hydrogen bonding strength of fluorine in the para position may be more effective.

\subsection{Kinetic parameters for free and immobilized AChE}

The kinetic parameters of free and immobilized $\mathrm{AChE}$ were investigated at different concentrations of substrate (from $186 \mathrm{mM}$ to $1120 \mathrm{mM}$ ). The data were plotted as Lineweaver-Burk graphs to calculate $V_{\max }$ and $K_{\mathrm{M}}$ values (Table 3, Fig. 5).
Kinetic parameters were studied for free and immobilized $\mathrm{AChE}$ at $\mathrm{pH}=8$ and $50{ }^{\circ} \mathrm{C}$ for [2AEPS- $(o$-F-Tet- $1 H)$ ]-AChE, $60{ }^{\circ} \mathrm{C}$ for [2AEPS$(m$-F-Tet- $1 H)]$-AChE and $70{ }^{\circ} \mathrm{C}$ for [2AEPS- $(p$-FTet- $1 H)$ ]-AChE. $K_{\mathrm{M}}$ and $V_{\max }$ from kinetic parameters were calculated from the Lineweaver-Burk plots [23]. As is known, the smaller the value of $K_{\mathrm{M}}$, the more efficient is the catalyst.

[2AEPS- $(o$-F-Tet-1H)]-AChE showed the smallest value of $\mathrm{Km}$. So, immobilized-[2AEPS- $(o-$ F-Tet- $1 H)$ ] is a good catalyst. The determined $K_{\mathrm{M}}$ for free and [2AEPS- $(o$-F-Tet-1H)]-AChE [2AEPS- $(m-$ F-Tet-1 $H)$ ]-AChE and [2AEPS-( $p$-F-Tet- $1 H)$ ]-AChE were found to be about $0.48,1.55$ and $5.75 \mathrm{mM}$, respectively. The $V \max$ value of the enzyme was decreased after immobilization onto [2AEPS-(o-F-Tet$1 H)$ ], [2AEPS- $(m$-F-Tet- $1 H)]$ and [2AEPS- $(p$-F-Tet$1 H)$ ]. Because of steric effects, interaction between the enzyme and substrate may be hindered.

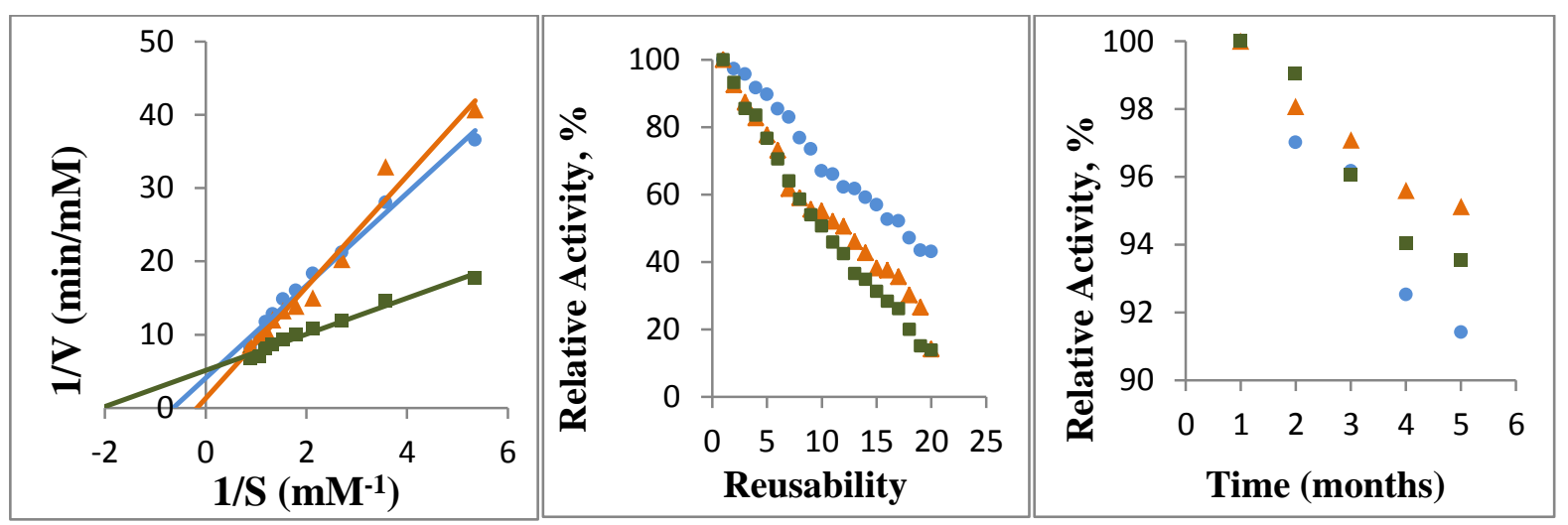

- 2AEPS- $(o$-F-Tet- $1 H)$-AChE, $\boldsymbol{\Delta} 2$ AEPS- $(m$-F-Tet-1 $H)$-AChE, • 2AEPS- $(p$-F-Tet- $1 H)$-AChE

Fig. 5. Kinetic parameters, storage stability and reusability,

Table 3

Kinetic parameters $\left(K_{M} / V_{\max } ; m M / m M \min ^{-1}\right)$ for free and immobilized AChE

\begin{tabular}{lccccc}
\hline \hline \multicolumn{2}{l}{$\begin{array}{l}\text { Working } \\
\text { conditions }\end{array}$} & \multicolumn{2}{l}{ Sphere } & Supports \\
\hline $\mathrm{pH}$ & $\begin{array}{c}\mathrm{t} \\
\left({ }^{\circ} \mathrm{C}\right)\end{array}$ & Free AChE & $\begin{array}{c}\text { [2AEPS- }(o \text {-F-Tet-1H)] } \\
\text {-AChE }\end{array}$ & $\begin{array}{c}\text { [2AEPS- }(m \text {-F-Tet-1H)] } \\
\text {-AChE }\end{array}$ & $\begin{array}{c}\text { [2AEPS- }(p \text {-F-Tet- } 1 H)] \\
\text {-AChE }\end{array}$ \\
\hline \multirow{2}{*}{8.0} & 50 & $0.146 / 1.85$ & $0.48 / 0.194$ & - & - \\
& 60 & $0.073 / 4.3$ & - & $1.55 / 0.25$ & - \\
& 70 & $0.12 / 1.68$ & - & - & $5.75 / 0.76$ \\
\hline \hline
\end{tabular}

\subsection{Storage stability and reusability}

As is known, the storage stability of enzymes is one of their most important characteris- tics; free enzymes lose their activity during storage [24]. Storage stability of the free and immobilized enzymes was determined every month when stored at $+4{ }^{\circ} \mathrm{C}$ under dry conditions. At the end of the 
first month, free enzyme activity decreased (retained $96.55 \%$ ); however the activity of the immobilized enzyme was preserved for [2AEPS- $(o-$ F-Tet-1 $H)$ ]-AChE, [2AEPS-( $m$-F-Tet- $1 H)$ ]-AChE and [2AEPS- $(p$-F-Tet- $1 H)]$-AChE, at 99.04, 98.07 and $97.01 \%$, respectively. Storage activity of the [2AEPS- $(m$-F-Tet- $1 H)]$-AChE was better than [2AEPS- $(o$-F-Tet- $1 H)]$-AChE and [2AEPS- $(p-\mathrm{F}-$ Tet-1H)]-AChE. These results indicate that the immobilized AChE retains its high enzymatic activity, which is very important for the preparation of the proposed enzyme support for industrial application. After five months, the free AChE, AChE immobilized onto [2AEPS- $(p$-F-Tet- $1 H)$ ], [2AEPS$(o$-F-Tet- $1 H)]$ and [2AEPS- $(m-$ F-Tet- $1 H)]$ retained $84.62,91.40,93.52$ and $95.12 \%$ of their original activity (in dry form), respectively.
As shown in Figure 5, the [2AEPS- $(p$-F-Tet$1 H)]$, [2AEPS- $(o$-F-Tet- $1 H)]$ and [2AEPS- $(m-\mathrm{F}-$ Tet- $1 H)$ ] were used repeatedly 20 times, and the residual activity was about $13.87,15.13$ and 43.40 $\%$ of their initial activity, respectively. As shown in Figure 6, the recycling stability performance of [2AEPS-(m-F-Tet-1H)] was better than the other studied supports.

\subsection{Evaluation on phosmet insecticide}

Changes in absorbance of tetrazole-tagged nanosphere are given in Figure 6; [2AEPS- $(o-\mathrm{F}-$ Tet-1H)]-AChE + phosmet insecticide, and [2AEPS- $(m$-F-Tet- $1 H)$ ]-AChE + phosmet insecticide, and [2AEPS- $(p$-F-Tet-1H)]-AChE + phosmet insecticide are shown in order. As it can be seen, there are changes in absorbance due to enzymephosmet (inhibitor) complex.
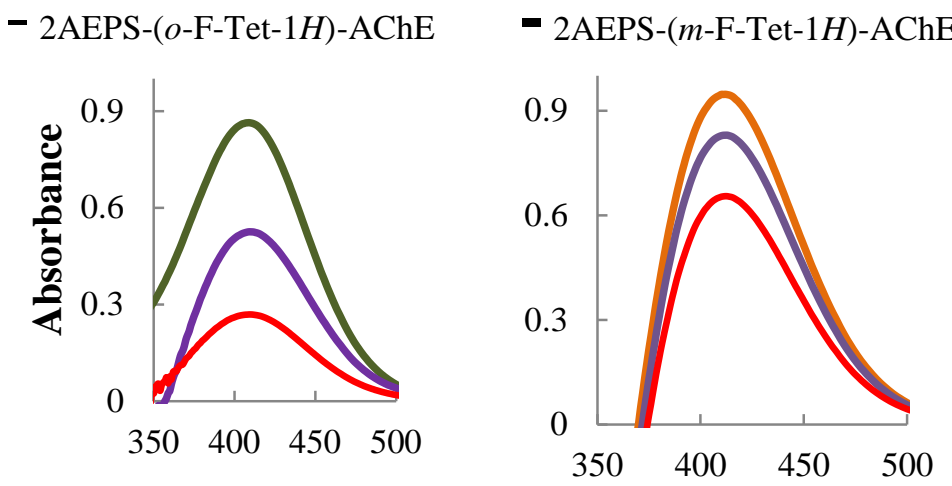

- 2AEPS- $(p-$ F-Tet-1H)-AChE

Wavelength (nm)

Fig. 6. Spectral change of phosmet insecticide in immobilized sphere $+30 \mu 1$ (purple line) and immobilized sphere $+50 \mu 1$ (red line)

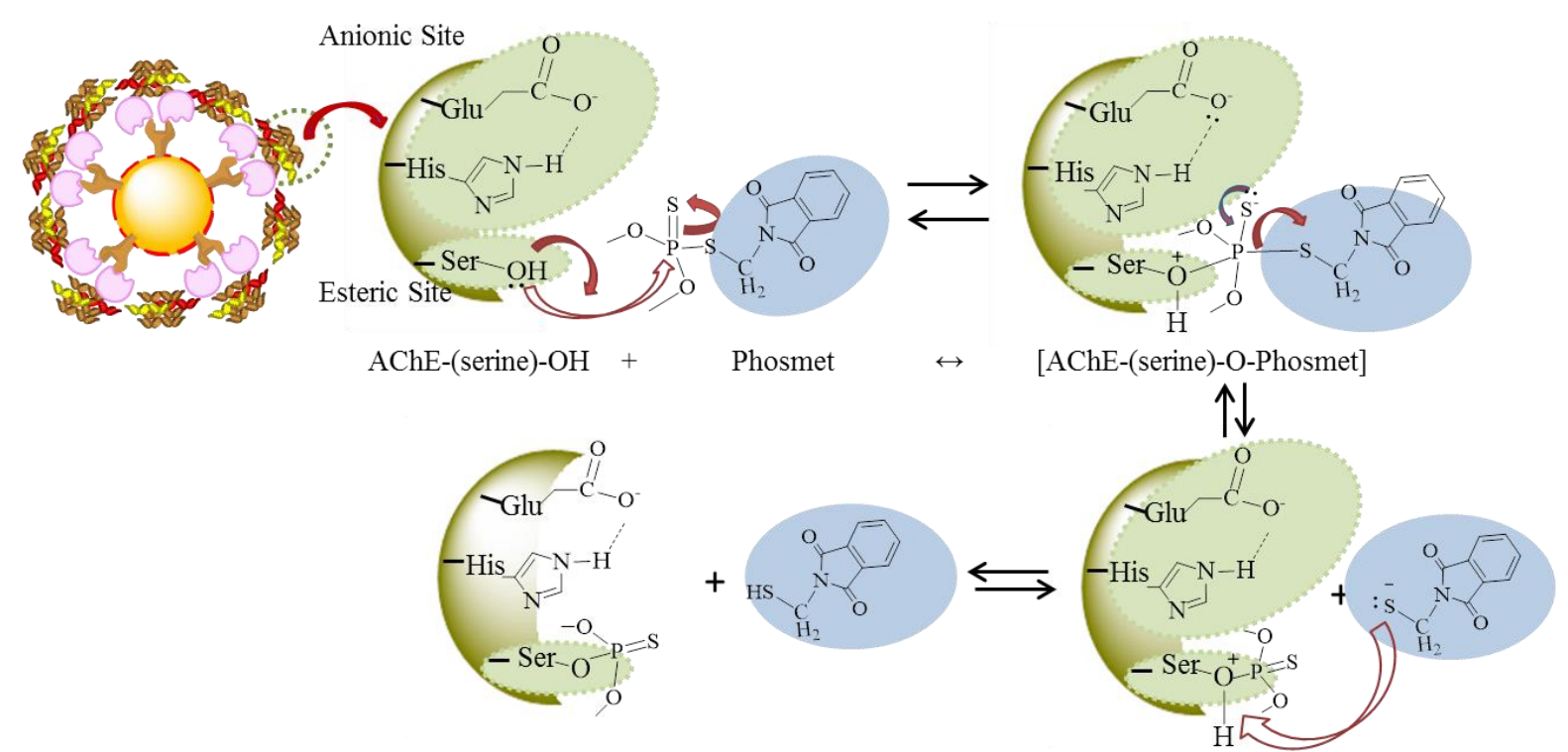

Fig. 7. Potential mechanism in between AChE and phosmet 
The anionic site and esteric sites of $\mathrm{AChE}$ are shown in Figure 7. The inactivity of AChE is dependent on the reaction between the AChEserine-OH and phosmet. The reaction begins with the nucleophilic attack by the catalytic serine hydroxyl on the carbonyl carbon of the ester bond. We may say that partially electropositive phosphorus is attracted to partially electronegative serine. Thus, one of the sulphur-oxygen bonds is broken; this provides strengthens the phosphorus-enzyme bond. According to Figure 6, the inhibitor effect on 2AEPS- $(o-\mathrm{F}-\mathrm{Tet}-1 H)$-AChE is greater than others.

\section{CONCLUSIONS}

Presented for the first time in this study, new ligated tetrazole derivatives on nanospheres have been synthesized for the identification of organophosphates. AChE immobilization has been successfully fabricated for the detection of a pesticide.
The apparent kinetic parameters of the immobilized enzyme and free enzyme were compared, and this showed that the Michaelis constant $\left(K_{\mathrm{M}}, V_{\max }\right)$ of the 2AEPS- $(o$-F-Tet- $1 H)$-AChE was higher than both 2AEPS- $(m$-F-Tet- $1 H)$-AChE and 2AEPS- $(p-$ F-Tet-1H)-AChE. Probably, stereochemical structure of 2AEPS-(o-F-Tet-1H)-AChE has been protected the three-dimensional structure of the enzyme by means of hydrogen bonds.

Hydrogen bonds are especially important between the hydrogen atoms in the $-\mathrm{NH}_{2} /-\mathrm{COOH}$ groups of the enzyme and the fluorine atom in orto position of the tetrazole molecule, because a fivering structure may occur with formation of this bond (green shaded region, Fig. 8). So, the threedimensional structure of the enzyme may be better protected. For this reason, in pesticide determination the 2AEPS- $(o$-F-Tet- $1 H)$-AChE may more easily interact with phosmet insecticide.
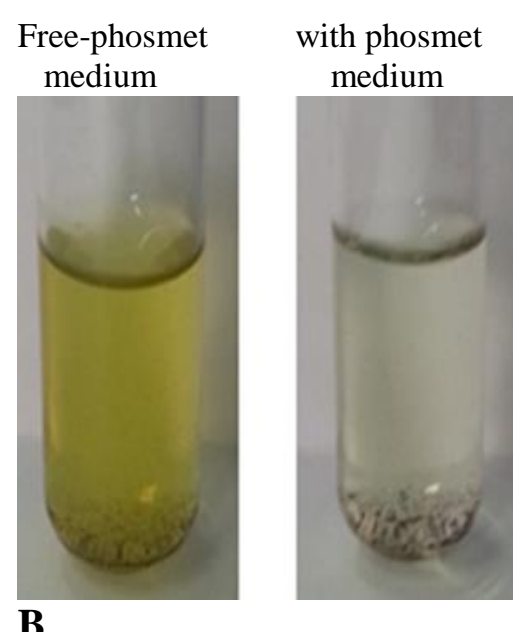

A

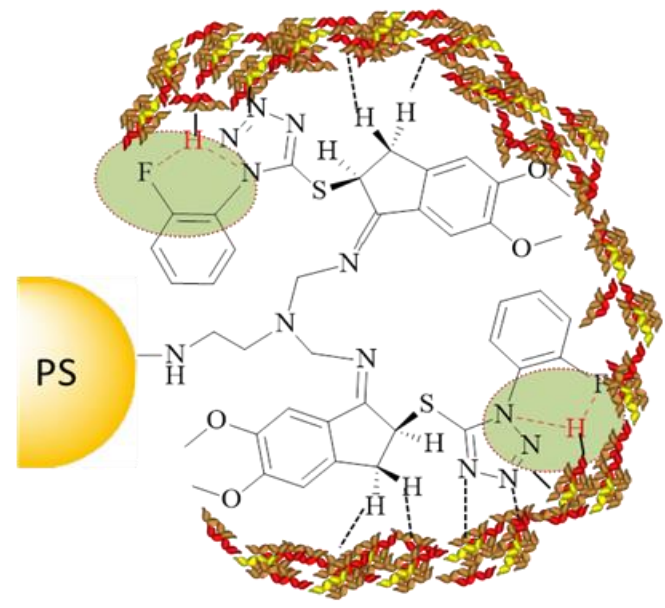

B

Fig. 8. Hydrogen bonds between enzyme and support material (A), photography related to phosmet insecticide (B)

\section{REFERENCES}

[1] F. Abrishami, M. Ebrahimikia, F. Rafiee, Synthesis of 5substituted $1 \mathrm{H}$-tetrazoles using a recyclable heterogeneous nanonickel ferrite catalyst, Appl. Organomet. Chem., 29, 730-735 (2015).

[2] B. Sreedhar, A. Suresh Kumar, D. Yada, $\mathrm{CuFe}_{2} \mathrm{O}_{4}$ nanoparticles: a magnetically recoverable and reusable catalyst for the synthesis of 5-substituted $1 \mathrm{H}$-tetrazoles, Tetrahedron Lett., 52, 3565-3569 (2011).

[3] V. Rama, K. Kanagaraj, K. Pitchumani, Syntheses of 5substituted $1 \mathrm{H}$-tetrazoles catalyzed by reusable $\mathrm{CoY}$ zeolite, J. Org. Chem., 76, 9090-9095 (2011).

[4] D. Kundu, A. Majee, A. Hajra, Indium triflate-catalyzed one-pot synthesis of 1 -substituted-1H-1, 2, 3, 4- tetrazoles under solvent-free conditions, Tetrahedron Lett., 50, 2668-2670 (2009).

[5] Y. Bhalla, E. Puri, P. Monga, S. Sapra, Medicinal and chemical aspects of tetrazoles: an overview, iP-Planet, 1, 20-30 (2013).

[6] F. Dehghani, A. R. Sardarian, M. Esmaeilpour, Salen complex of $\mathrm{Cu}(\mathrm{II})$ supported on superparamagnetic $\mathrm{Fe}_{3} \mathrm{O}_{4} \cdot \mathrm{SiO}_{2}$ nanoparticles: An efficient and recyclable catalyst for synthesis of 1 - and 5-substituted $1 \mathrm{H}$ tetrazoles, J. Org. Chem.,743, 87-96 (2013).

[7] M. L. Kantam, K. B. Shiva Kumar, C. H. Sridhar, Nanocrystalline $\mathrm{ZnO}$ as an efficient heterogeneous catalyst for the synthesis of 5-Substituted $1 H$-Tetrazoles, Adv. Synth. Catal., 347, 1212-1214 (2005).

[8] Q. Q Ren, L. Y. Bai, X. S. Zhang, Z. Y. Ma, B. Liu, Y. D. Zhao, Y. C. Cao, Preparation, modification and 
application of hollow gold nanospheres, J. Nanomater. DOİ:10.1155/2015/534070 (2015)

[9] N. Kurnaz Yetim, E. Hasanoğlu Özkan, B. Danış, H. Tümtürk, N. Sarı, Research on the repeated use of novel ferrocene tagged nanomaterial for determination of glucose, Int. J. Polym. Mater. Polym. Biomater., 64, 888-893 (2015).

[10] M. B. Brena, F. Batista-Viera, Methods in Biotechnology: Immobilization of Enzymes and Cells, Second Edition Edited by: J. M. Guisan, Humana Press Inc., Totowa, NJ.

[11] E. Hasanoğlu Özkan, N. Kurnaz Yetim, H. Tümtürk, N. Sar1, Immobilization of acetylcholinesterase on Pt(II) and $\mathrm{Pt}(\mathrm{IV})$ attached nanoparticles for the determination of pesticides , Dalton. Trans., 44, 16865-16872 (2015).

[12] A. P. Periasamy, Y. Umasankar, S. M. Chen, Nanomaterials-acetylcholinesterase enzyme matrices for organophosphorus pesticides electrochemical sensors: A Review, Sensors, 9, 4034-4055 (2009).

[13] N. A. Buckley, D. Roberts, M. Eddleston, Overcoming apathy in research on organophosphate poisoning, The $B$ M J, 329, 1231-1233 (2004).

[14] J. Warner, S. Andreescu, An acetylcholinesterase (AChE) biosensor with enhanced solvent resistance based on chitosan for the detection of pesticides, Talanta, 146, 279-284 (2016).

[15] J. C. Kauer, W. A. Sheppard, 1-Aryltetrazoles synthesis and properties, The J. Org. Chem., 32, 3580-3592 (1967).

[16] E. Lieber, T. Enkoji, Synthesis and properties of 5(Substituted) mercaptotetrazoles, J. Org. Chem., 26, 4472-4479 (1961).
[17] A. Dișli, M. Salman, Synthesis of some new 5substituted $1 H$-tetrazoles, Russ. J. Org. Chem., 45,151153 (2009).

[18] A. Dişli, S. Mercan, S. Yavuz, Synthesis and antimicrobial activity of new pyrimidine derivatives incorporating $1 \mathrm{H}$-tetrazol-5-ylthio moiety, J. Heterocycl. Chem, 50, 1446-1450 (2013).

[19] G. D. Çelik, A. Dişli, Y. Öner, L. Açık, Synthesis of some novel amino and thiotetrazole purine derivatives and investigation of their antimicrobial activity and DNA interactions, Med. Chem. Res., 22, 1470-1479 (2013).

[20] S. Muralikrishna, P. Raveendrareddy, L. K. Ravindranath, S. Harikrishna, P. R Jagadeeswara, Synthesis characterization and antitumor activity of thiazole derivatives containing indole moiety bearing-tetrazole, Der Pharma Chem., 5, 87-93 (2013).

[21] E. Bozkır, N. Sarı, H. Öğütçü, Polystyrene containing carbinolamine/azomethine potentially useful as antimicrobial agent: synthesis and biological evaluation, $J$. Inorg. Organomet. Polym. Mater., 22, 1146-1155 (2012).

[22] N. Özdem, E. Hasanoğlu Özkan, N. Sarı, F. Arslan, H. Tümtürk, Immobilization of Glucose Oxidase attached to new nanospheres including azomethine, Macromol. Res., 22, 1282-1287 (2014).

[23] M. C. Moscatelli, A. Lagomarsino, A. M. V. Garzillo, A. Pignataro, S. Grego, $\beta$-Glucosidase kinetic parameters as indicators of soil quality under conventional and organic cropping systems applying two analytical approaches, Ecol. Indic., 13, 322-327 (2012).

[24] E. Hasanoğlu Özkan, N. Kurnaz Yetim, D. Nartop, N. Sar1, J. Ind. and Eng. Chem., 25, 180-185 (2015). 